\title{
Airbus-A Solid, Reliable and Trustworthy Long-Term Partner for China
}

\author{
Gang Xu
}

\begin{abstract}
Since it first entered the Chinese market in 1967, Airbus has been actively participating in China's process of reform and opening-up. Airbus thrives on the competition and innovation in the Chinese market and is using a holistic development strategy when it comes to future growth in China. Integration in terms of manufacturing with our completion and delivery center in Tianjin, cooperation in technology areas like big data, AI and new energy as well as China's efforts toward carbon neutrality create even more opportunities for Airbus to play a role in China's development strategies.
\end{abstract}

Keywords Competition and innovation $\cdot$ Holistic development strategy $\cdot$ Tianjin completion and delivery center $\cdot \operatorname{Big}$ data $\cdot \mathrm{AI} \cdot \mathrm{New}$ energy $\cdot$ Carbon neutrality

\section{Airbus China's Past and Present}

Airbus saw the potential of the Chinese market long ago, entering the Chinese market back in 1967, which gave it a rare strategic opportunity. In addition to commercial aircraft, Airbus is also the world's leading helicopter manufacturer as well as a European leader providing tanker, combat and military transport aircraft. It has also become one of the world's leading space companies.

In 1967, the Airbus Helicopter (formerly known as Eurocopter) was the first to enter the Chinese market. In 1985, with the delivery of an Airbus A310 to the CAAC East China Regional Administration, the predecessor of China Eastern Airlines, Airbus' commercial aircraft officially entered the Chinese market. In 1998, Airbus Defence and Space jointly established Beijing Spot Image Co. Ltd. with the Aerospace Information Research Institute and the Chinese Academy of Sciences, resulting in the first commercial company to provide earth observation satellite image products and services in the Chinese market.

G. $\mathrm{Xu}(\otimes)$

Airbus China, Beijing, China 


\section{The Chinese Market is a Huge Indispensable Strategic Market}

The Chinese market has been a rare strategic opportunity for Airbus. Since it first entered the Chinese market in 1967, Airbus has been actively participating in China's process of reform and opening-up, witnessing firsthand the vigorous development of the aviation industry. Over the past decade, Airbus has delivered about $20 \%$ of its global production to Chinese customers annually and as of today some 2,000 Airbus aircraft are operated by Chinese customers, which means that China has the largest number of Airbus aircraft in service of any country in the world.

In 2020, despite the impact of the pandemic, Airbus delivered 99 commercial aircraft to the Chinese market, accounting for $17.5 \%$ of its total global output. While this is less than $20 \%$, there has been an obvious trend toward increase sales. In the first quarter of 2020, the effect of the pandemic resulted in the number of aircraft delivered by Airbus to Chinese customers accounting for only $6 \%$ of its total global delivery that quarter. This rose slowly to $9 \%$ in the second quarter, $20 \%$ in the third quarter and $24 \%$ in the fourth quarter. This clearly shows that China's market experienced a sharp recovery and has a strong resilience. In October last year, the Airbus A320 final assembly line in Tianjin successfully delivered its 500th aircraft.

Looking forward to the future, Airbus is confident that it will continue to grow in China. With a population of 1.4 billion, China is the second-largest aviation market in the world, but the number of flights taken per capita is only 0.5 per year. In other words, only one in two people travel by air once a year, which is a far cry from the United States, the world's largest aviation market, where the number of flights per capita is 2.8 per year. We believe that China can maintain an annual growth rate higher than the world's average in the global aviation market. A market forecast by Airbus also predicts that in the next decade, China will surpass the United States to become the world's largest aviation market. In this sense, there is huge room for development and China's market will provide even more opportunities in the future.

\section{Globalization is Our Philosophy}

China is not only a huge market for Airbus, it is also an important partner. The Airbus final assembly line in Tianjin has attracted many other leading enterprises in the aviation industry to Tianjin. It has also enabled many Chinese enterprises to enter the international market through the Airbus project.

With the outbreak of COVID-19, there has been talk of decoupling from China and moving toward de-globalization, which we believe is very dangerous and unrealistic. As a natural promoter, practitioner and beneficiary of globalization, the aviation industry would naturally be a direct victim of "anti-globalization". The aviation industry has a global supply chain, and its airworthiness standards and markets are also international and globalized. We have seen that during the pandemic, with 
extensive restrictions on people-to-people and international exchanges, the aviation industry was the first industry to feel the impact. It is for this reason that aviation has always been rooted in the concept of globalization, practicing it, promoting it and ultimately benefiting from it. The aviation industry has been and will continue to be a rapid and effective communication platform that promotes connections between people, places, cultures, philosophies and economies. Globalization is our philosophy.

Globalization is also the nature of Airbus, because from the moment it was founded, Airbus has been a consortium composed of diverse countries. One of the core beliefs of Airbus is inclusiveness, which shares similar elements with globalization. After all, Europe only accounts for 30\% of Airbus's global market, while $70 \%$ of its market is outside Europe. This has led us to go beyond our own market. At the same time, markets like China are not only important and strategic, they are also the force that has helped Airbus to become more competitive on a global scale. China also has a number of emerging science and technology industries, while it continues to grow in the area of finance. We believe that a partnership with China can result in a win-win situation.

I am the first Chinese CEO of Airbus China, which is a proof of Airbus's unwavering localization strategy ("localization" here means that local people lead in the local market). From the perspective of Airbus HQ, "localization" outside of the home countries is a key part of the company's globalization strategy. At present, Airbus has about 2,000 employees in China, with a localization rate of $94 \%$. When the Tianjin final assembly line was put into operation in 2008, we had a total of 450 employees in the factory, 150 of which were expatriates, accounting for one-third of all employees. At that time, the company developed its localization roadmap and five years later the number of foreign employees dropped from 150 to 18. Airbus now has an outstanding group of talented Chinese employees who have an excellent level of competitiveness in terms of operational efficiency and quality. This decision shows that Airbus is determined to be inclusive, multi-cultural and fully localized in major strategic markets, which also reflects its determination to become more international.

\section{Competition is an Important Guarantee for the Healthy Development of the Aviation Industry}

The potential of China's market is huge, but there is also no lack of cost-effective locally branded civil aircraft, such as the C919. As a global aircraft manufacturing giant, how does Airbus view the fierce competition in the Chinese market?

First, Airbus would like to express its heartfelt congratulations on the introduction of the C919 to the Chinese market and the launch of the CR929 project. Competition is important for the healthy development of the aviation industry. Airbus is not the first aircraft manufacturer to enter the aviation market. Airbus was born from competition, 
and its continued success also comes from competition. Competition urges Airbus to invest more in R\&D and listen to the market and its customers. We hope the result will be more efficient, more cost-competitive and more sustainable aircraft, all of which comes from the driving force brought by competition.

In the future, there will be still many development opportunities in China and the global aviation market, and we encourage fair and healthy competition. As important participants, Commercial Aircraft Corporation of China, Ltd. (COMAC), AVIC and many emerging private enterprises have stepped into the aviation industry-a "crown jewel" of the high-end manufacturing industry. Airbus has been cooperating with some of these companies for a long time, and look forward to exploring future opportunities together.

\section{Airbus's Vision for China is Long Term, Diversified and Strategic}

Cooperation between Airbus and China is multifaceted and comprehensive. Airbus and AVIC jointly established the Airbus (Beijing) Engineering Center Co., Ltd in 2005. This joint venture is responsible for 5\% of the design of Airbus' A350XWB, the latest generation wide-body aircraft. Airbus set up its first aircraft final assembly line outside Europe in Tianjin in 2008. Airbus has also worked to provide Chinese airlines with greater benefits in the services and technical support areas. These moves include the founding of the AIRTAC China, the first aircraft emergency response center outside Europe, established in April last year amid the COVID-19 outbreak.

Airbus's China model must be viewed in a holistic way from multiple dimensions and perspectives. This model has proved to be successful, and we will continue along this path as we still will have a lot of room for development. In 1995, our market share in China was less than 9\%, but in 2013, it reached 50\%. We hope this model will also serve to inspire the global aviation industry through its success, enabling other companies to develop and grow in China, which is a massive and uniquely strategic market.

With the outbreak of COVID-19, China was the first and the only major economy in the world to register positive growth in 2020. China's GDP grew 2.3\% in 2020, which was remarkable in the face of the unprecedented challenge of the pandemic. From the middle of last year, China was able to effectively control the spread of the virus, which was reflected in the aviation industry, often used as a "barometer" to reflect the state of the pandemic. By the second half of last year, especially in the fourth quarter, China's domestic passenger traffic returned to pre-pandemic levels, speaking to China's remarkable achievements in prevention and control. Airbus is confident that China's economy and market will make the right moves going forward.

What will the future look like? In the short run, the future is unpredictable and fragile. With new variants emerging all over the world, the question of whether current vaccines will be effective, and the issue of mutual vaccine recognition in 
various countries will create uncertainty. The state of recovery is precarious-with sporadic outbreaks in some Chinese cities, air passenger trips during the Spring Festival were only $60 \%$ of what they were pre-pandemic.

However, we remain optimistic on the long-term development of the global aviation industry, especially in China. China's large population provides a huge untapped potential market for the aviation industry and will produce an even greater demand for air travel. Furthermore, increased urbanization, new infrastructure projects and better public services will also create new demand.

\section{Broad Prospects for Future Cooperation Between Airbus and China}

It has been 36 years since Airbus delivered its first aircraft to China in 1985. Today, all Airbus commercial aircraft have parts made in China. Airbus's strategy in China is unswerving, and Airbus will continue working to become a solid, reliable and trustworthy long-term partner and a core member in the "closed loop" of China's aviation industry. There is great potential for expanded cooperation in the future.

First, we need to deepen the existing cooperation and expand to the latest generation of wide-body aircraft following the opening of the completion and delivery center in Tianjin. We delivered the first A350 in Tianjin in early 2021. We have also started a fuselage equipping project in Tianjin for the A320 family aircraft. These are all further extensions of our existing cooperation projects.

We are also considering increased integrated cooperation with China in new technology areas like big data, artificial intelligence and new energy. This is why we chose Shenzhen to set up the world's second Airbus innovation center, the only one outside the United States. This is also the reason why we also established an engineering center with our Chinese partners in Beijing.

Third, China promises to reach its peak carbon dioxide emissions around 2030 and achieve carbon neutrality by 2060 , which is an enormous goal that demonstrates China's commitment to acting as a major player in global governance.

Airbus is an aviation leader. The reason for this is that we not only aim to produce economically competitive aircraft that are reliable and safe, but as the aviation industry accounts for $2.5 \%$ of global carbon emissions, we also feel duty-bound to promote efforts to reduce emissions throughout the industry. Airbus has announced that it expects to launch its first zero-emission aircraft powered by hydrogen in 2035 .

I am constantly thinking about what role Airbus can play in China's key development strategies. I believe that the dual circulation model, in which domestic and overseas markets reinforce each other, is very good news for the aviation industry. To ensure sustainable and strong development in the aviation industry, air travel must be a product that most people can afford, rather than a privilege for a small circle of "elites". China has 400 million people that are "middle class" and releasing their consumer potential will be the key to the success of domestic circulation. 
As growth in domestic circulation will be the mainstay in China, urbanization, equal access to infrastructure and improved public service will also see further development, which will undoubtedly create great potential for both commercial and general aviation. From the supply side, China needs to upgrade domestic industries to better meet the market demand. As the "crown jewel" of the high-end manufacturing industry, aviation is the next key industry in China.

We have achieved a win-win result in our partnerships with AVIC and other partners throughout the industry chain, including airlines that have cooperated with us for many years. We will stick to this path of win-win cooperation and mutual benefit, striving to contribute to China's transition to become an aviation powerhouse, which will also help Airbus maintain its leading position in the aviation market.

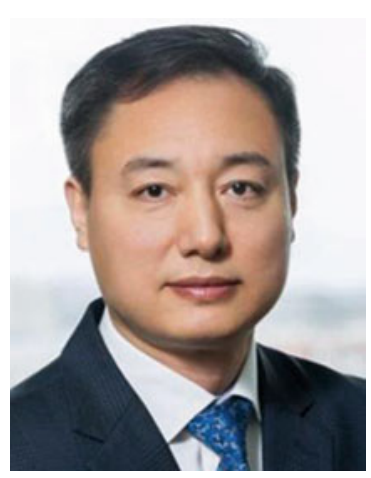

Gang Xu was appointed CEO of Airbus China on January 8, 2018. As country head of Airbus China, he is responsible for all Airbus Commercial Aircraft business activities and leading the company's Helicopters and Defence and Space businesses in China. In 2005, Gang Xu started to actively participate in the Airbus A320 Family Final Assembly Line project when he was director of the Investment Promotion Bureau of Tianjin Free Trade Zone. From 2008 to 2011, Gang Xu was Deputy GM of the Airbus Tianjin A320 Family Final Assembly Line (FAL), and in 2011, he was appointed Chairman of Board of the FAL. In 2014, Gang Xu was nominated and worked full time as a Standing Committee Member of 17th Communist Youth League of China's Central Committee and Party Secretary of the Tianjin Youth League until 2017.

Background: Having been a part of Airbus China since 2005, Gang Xu rose to become the company's CEO in 2018. When he first worked with Airbus, the company was preparing to set up its first aircraft assembly line outside of Europe. Four Chinese cities bid during the site selection process-Tianjin, Shanghai, Xi' an and Zhuhai. Gang Xu worked in the Tianjin Binhai New Area and participated in the entire bidding process. Ultimately, Tianjin was chosen as the location for the final assembly line project. Representing the local government, the Tianjin Free Trade Zone and the Aviation Industry Corporation of China, Ltd. (AVIC) established a joint venture with Airbus. Gang $\mathrm{Xu}$ was appointed as the Vice General Manager of the joint venture company, jointly managing the assembly line together with the General Manager, who was nominated by Airbus. The assembly line has been operating successfully for 13 years and delivered its 500th A320 series plane in Tianjin in 2020. 
Open Access This chapter is licensed under the terms of the Creative Commons AttributionNonCommercial-NoDerivatives 4.0 International License (http://creativecommons.org/licenses/bync-nd/4.0/), which permits any noncommercial use, sharing, distribution and reproduction in any medium or format, as long as you give appropriate credit to the original author(s) and the source, provide a link to the Creative Commons license and indicate if you modified the licensed material. You do not have permission under this license to share adapted material derived from this chapter or parts of it.

The images or other third party material in this chapter are included in the chapter's Creative Commons license, unless indicated otherwise in a credit line to the material. If material is not included in the chapter's Creative Commons license and your intended use is not permitted by statutory regulation or exceeds the permitted use, you will need to obtain permission directly from the copyright holder.

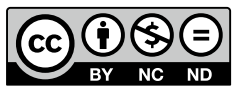

